\title{
Knowledge of the nursing team on pressure ulcer prevention
}

\author{
Conhecimentos da equipe de enfermagem sobre prevenção de úlceras por pressão \\ Conocimientos del equipo de enfermería acerca de prevención de úlceras por presión
}

\section{Nariani Souza Galvão', Maria Alice Barbosa Serique", Vera Lúcia Conceição de Gouveia Santos', Paula Cristina Nogueira"II}

'Universidade de São Paulo, School of Nursing, Postgraduate Program in Nursing in Adult Health. São Paulo, Brazil.

"Universidade Federal do Amazonas, School of Nursing of Manaus, Undergraduate Program in Nursing. Manaus, Amazônas, Brazil.

I' Universidade de São Paulo, School of Nursing, Department of Medical-Surgical Nursing. São Paulo, Brazil.

How to cite this article:

Galvão NS, Serique MAB, Santos VLCG, Nogueira PC. Knowledge of the nursing team on pressure ulcer prevention. Rev Bras Enferm [Internet]. 2017;70(2):294-300. DOI: http://dx.doi.org/10.1590/0034-7167-2016-0063

\section{Submission: 04-05-2016 Approval: 09-01-2016}

\section{ABSTRACT}

Objective: describe and analyze the nursing team's knowledge about classification, evaluation and measures to prevent pressure ulcers (PU) in patients hospitalized in the ICU of a teaching hospital in the city of Manaus. Method: a descriptive and exploratory study was conducted after approval by a research ethics committee. Data were collected using a validated instrument. The study sample was made up of 40 nursing staff members, of whom 14 were nurses and 26 were nursing technicians/aides. Data were analyzed through descriptive statistics and Student's t-test, with value of $p<0.05$. Results: the overall mean of hits was $63.4 \%$ for technicians/aides and $51.4 \%$ for nurses, with statistically significant differences between the groups only for the PU prevention category $(p<0.001)$. Conclusion: a deficit of knowledge on PU prevention was found among nurses and nursing technicians/aides, demanding the training of these professionals. Descriptors: Pressure Ulcer; Prevention and Control; Nursing Team; Stomal Therapy; Hospital.

\section{RESUMO}

Objetivo: Descrever e analisar os conhecimentos da equipe de enfermagem acerca da classificação, avaliação e medidas de prevenção de úlceras por pressão (UP), em pacientes internados na UTI de um Hospital Universitário da cidade de Manaus. Método: Estudo descritivo e exploratório aprovado por Comitê de Ética em Pesquisa. Os dados foram coletados por meio de um instrumento validado. Amostra de 40 funcionários, sendo 14 enfermeiros e 26 técnicos/auxiliares de enfermagem. Os dados foram analisados por estatística descritiva e teste $t$ de Student, com valor de $\mathrm{p}<0,05$. Resultados: As médias globais de acertos foram $63,4 \%$ para os técnicos/auxiliares e $51,4 \%$ para os enfermeiros, com diferença estatisticamente significativa entre os grupos somente para a categoria de prevenção de UP $(p<0,001)$. Conclusão: Déficit de conhecimentos sobre a prevenção de UP entre enfermeiros e técnicos/auxiliares de enfermagem, tornando mandatória a capacitação desses profissionais.

Descritores: Úlcera por Pressão; Prevenção e Controle; Equipe de Enfermagem; Estomaterapia; Hospitalar.

\section{RESUMEN}

Objetivo: describir y analizar los conocimientos del equipo de enfermería sobre clasificación, evaluación y medidas de prevención de úlceras por presión (UP) en pacientes internados en UTI de Hospital Universitario de la ciudad de Manaos. Método: estudio descriptivo y exploratorio, aprobado por Comité de Ética en Investigación Datos recolectados mediante instrumento validado. Muestra de 40 trabajadores, 14 de ellos enfermeros y 26 técnicos/auxiliares de enfermería. Los datos fueron analizados por estadística descriptiva y test $t$ de Student, con valor de $p<0,05$. Resultados: los promedios globales de aciertos fueron de $63,4 \%$ para los técnicos/auxiliares y del 51,4\% para los enfermeros, con diferencia estadísticamente significativa entre los grupos sólo para la categoría de prevención de UP $(p<0,001)$. Conclusión: detectado déficit de conocimientos sobre prevención de UP entre enfermeros y técnicos/auxiliares de enfermería, resultando imperiosa la capacitación de estos profesionales.

Descriptores: Úlcera por Presión; Prevención y Control, Grupo de Enfermería; Estomaterapia; Hospitalaria.

$$
\text { CORRESPONDING AUTHOR Nariani Souza Galvão E-mail: narigalvao@ufam.edu.br }
$$




\section{INTRODUCTION}

Despite the technology and scientific advances in the field of health, the occurrence of pressure ulcer (PU) in hospital institutions is still a serious problem that results in physical and psychological suffering for patients and their families. Moreover, it increases the expenditure of the health system's resources, which are typically scarce ${ }^{(1)}$.

Although studies about PU prevention and treatment have advanced in the last few years, some authors ${ }^{(2)}$ consider the need for consistent improvement of the nursing team, including nurses, in this field to provide quality nursing care.

It is noteworthy that, despite international guidelines on PU prevention and treatment for clinical practice (Agency for Healthcare Research and Quality - AHRQ; European Pressure Ulcer Advisory Panel - EPUAP; National Pressure Ulcer Advisory Panel - NPUAP and National Institute for Health and Care Excellence NICE), few nurses use these, sometimes for lack of knowledge, or insufficient materials and equipment required for this practice ${ }^{(3)}$.

National and international authors ${ }^{(4-5)}$ consider the implementation of protocols in healthcare institutions as a positive way to reduce the PU incidence rates. However, despite the relevance of these measures to reduce harm to patients with PU, these prevention protocols are not much used in hospital institutions ${ }^{(5)}$.

National and international studies on nursing professionals' knowledge about prevention and treatment of $\mathrm{PU}^{(6-7)}$ result from a concern of experts regarding the high coefficients of prevalence and incidence that still exist in health institutions and at domiciles. Most of the studies showed the nursing team's lack of knowledge in some specific areas, including PU ${ }^{(6-7)}$ preventive measures.

Broadening the nursing team's knowledge and implementing evidence-based practices entail benefits to reduce both length of hospital stay and the number of patients suffering from this condition ${ }^{(8)}$.

This topic is of utmost relevant to nurses' clinical practice because of the constant need for assessing the nursing team's knowledge, and the scarcity of publications about PU in the Amazon Region.

\section{OBJECTIVES}

The objective of this study was to describe and analyze the nursing team members' knowledge about the classification, evaluation and prevention of PU in patients hospitalized in the intensive care unit (ICU) of a teaching hospital in the city of Manaus.

\section{METHOD}

\section{Ethical aspects}

The research project was approved by the Human Research Ethics Committee of the Nursing School of Manaus.

\section{Study design, setting and period}

This descriptive and exploratory study, with a quantitative approach, consists in an end-of-course paper, carried out with an ICU nursing team at the Teaching Hospital Getúlio Vargas, in the city of Manaus. Data were collected from March to April 2014.

\section{Population or sample: inclusion criteria}

The population of the study was made up by 48 nursing staff members, and the sample consisted in 40 staff members: 14 nurses, 20 nursing technicians and six nursing aides. The sample was selected by convenience, with the following inclusion criteria: (i) being at the hospital and (ii) working directly with care to adults and elderly in the ICU for the period of application of the instrument, and voluntarily accepting to participate in the study.

\section{Study protocol}

Data were collected using two instruments: the first was made up of sociodemographic data (sex, age, profession, length in the profession and work in the ICU). The second one had 41 truefalse questions, divided into the categories of PU evaluation and classification, with eight items and 33 questions about PU prevention, named Pieper's Pressure Ulcer Knowledge Test ${ }^{(9)}$ in its version adapted and validated to Brazil(10). Considering that the original document dates back to 1995, and that several consensuses and studies have been developed since then, the instrument is being reviewed, according to Professor Barbara Pieper.

The employees answered the instrument individually, during the working hours. After filling it in, the instrument was placed in an envelope and delivered to the researcher with no identification, thus ensuring anonymity. In this study, the respondents with proper knowledge about the topic were those who corrected $90 \%$ or more of the items related to the questions and categories of the knowledge test.

Participation in the study was volunteer, after authorization and signature of a free and informed consent form, in two copies. Respondents were given a copy of the form and the researcher kept the other.

\section{Analysis of results and statistics}

Data were analyzed using the statistical software SPUS 17.0. Analyses were made using the Shapiro-Wilk's normality test; the F test to verify variance homogeneity and, then, Student's t-test for independent samples. The information collected was tabulated in an Excel spreadsheet. Descriptive statistics was used to design measures of central tendency, frequencies and dispersion for demographic variables. The significance level adopted was $5 \%(\mathrm{p}<0.05)$.

\section{RESULTS}

The prevailing age in the sample ranged between 36 and 40 years $(34.8 \%)$ followed by 41 to 45 years $(20.5 \%)$. Most participants were women $(81.4 \%)$; with profession length of 6 to 10 years $(37.2 \%)$; and length of work in the ICU from 6 to 10 years $(46.5 \%)$.

Considering the mean percentages of overall hits for the 41 questions among the professional groups, the nursing technicians/aides scored $63.4 \%(\mathrm{SD}=8.0)$ on average, whereas nurses scored $51.4 \%(\mathrm{SD}=9.7)$ on average.

The questions related to PU evaluation and classification are shown in Table 1.

The highest mean percentage in the stage of PU evaluation and classification was $91.6 \%$, which was achieved by nurses for 
the question referring to the blister on the calcaneus region (item $33)$, as a characteristic of the lesion. The lowest mean (33.3\%) was also achieved by nurses and referred to the PU stage II classification (item 20). Regarding the nursing technicians/aides, their highest hit mean (89.2\%) was in the question referring to the PU stage IV classification (item 9) and lowest mean in item 6 , related to the PU classification, but of stage III (37.5\%). Except for the description of PU stage IV (item 9), where the total mean hit was $82.5 \%$, there is a shortage of knowledge mainly about the PU classification in stages I, II and III (items 1, 20 and 6 , respectively), where the total respondents of both groups presented mean hits of $55.0 \%, 42.5 \%$ and $45.0 \%$, respectively. Item 33, related to the presence of a blister on the calcaneus, reached the highest total mean of hits $(87.5 \%)$. No professional reached $100 \%$ of hits for the questions in this stage.

Regarding the overall performance of the two groups in the category PU evaluation and classification, the technicians/ aides reached a mean percentage of $55.1 \%(S D=16.4 \%)$ hits and nurses $44.0 \%(S D=20.6)$.

The questions related to PU prevention are shown in Table 2.

The results in Table 2 show a variation of mean hits from 33.3\% to $100 \%$ among nurses and from $17.8 \%$ to $100 \%$ among nursing technicians/aides in the category PU preventive measures. Moreover, nurses achieved $100 \%$ of hits in only one question (item 40), about the development of educational programs in the institution. Nursing technicians/aides, in turn, reached the maximum score in three questions (items 22, 27 and 39) and 96.4\% of hits in other four (items 21, 26, 37 and 41) related to specific (cleanness, moisture, friction) and general (risk evaluation, guidance to family members, systematization of measures) measures of prevention. The lowest mean of hits $(17.8 \%)$ was achieved by technicians/ aides in item 5 , related to the massage on regions of bone prominence, whereas nurses presented the lowest mean of hits $(33.3 \%)$ in four items $(4,8,18$ and 37), related to friction, use of warm water and relief of pressure for patients in sitting position.

Regarding the overall performance of both groups in the category PU preventive measure, technicians/aides achieved a mean percentage of $65.1 \%(\mathrm{SD}=8.9)$ hits, once again higher than that of nurses $(52.9 \%, \mathrm{SD}=8.7)$.

As shown in Table 3, there were statistically significant differences between the professional groups regarding the mean percentage of hits both for the category of PU preventive measures $(p<0.001)$ and for all questions $(p<0.001)$, which were higher among technicians/aides when compared with nurses.

Table 1 - Mean percentage of hits of professional groups regarding PU classification and evaluation, Manaus, Amazonas, Brazil, 2014

\begin{tabular}{|c|c|c|c|c|c|c|}
\hline \multirow{2}{*}{ Pressure ulcer evaluation and classification } & \multicolumn{2}{|c|}{ Nurses } & \multicolumn{2}{|c|}{$\begin{array}{l}\text { Nursing } \\
\text { technicians/aides }\end{array}$} & \multicolumn{2}{|c|}{ Total } \\
\hline & f & $\%$ & f & $\%$ & f & $\%$ \\
\hline $\begin{array}{l}1 \text { - Stage } * \text { I pressure ulcers are defined as intact skin with hyperemia of a localized area and } \\
\text { non-blanchable redness or different color from the surrounding area }(\mathrm{T})\end{array}$ & 8 & 66.6 & 14 & 50.0 & 22 & 55.0 \\
\hline 6 - Stage III pressure ulcers present partial tissue loss, involving the epidermis (F) & 9 & 75.0 & 9 & 37.5 & 18 & 45.0 \\
\hline $\begin{array}{l}9 \text { - Stage IV pressure ulcers present total tissue loss, with intensive destruction and necrosis of the } \\
\text { tissue or damage to the muscles, bones, or supporting structures }(T)\end{array}$ & 8 & 66.6 & 25 & 89.2 & 33 & 82.5 \\
\hline 20 - Stage II pressure ulcers present loss of dermis in its total thickness $(F)$ & 4 & 33.3 & 13 & 46.4 & 17 & 42.5 \\
\hline 31 - Pressure ulcers are sterile wounds (F) & 8 & 66.6 & 17 & 60.7 & 25 & 62.5 \\
\hline 32 - Lesions can develop faster on a region of the skin with pressure ulcer scar than on intact skin (T) & 7 & 58.3 & 23 & 82.1 & 30 & 75.0 \\
\hline 33 - A blister on the calcaneus region is not concerning $(F)$ & 11 & 91.6 & 24 & 85.7 & 35 & 87.5 \\
\hline 38 - Stage II pressure ulcers can be extremely painful because of the exposure of nerve endings (T) & 8 & 66.6 & 16 & 57.1 & 24 & 60.0 \\
\hline
\end{tabular}

Note: True (T); False (F); Frequency: f; *Stage: the current word for stage is category, according to the National Pressure Ulcer Advisory Panel/European Pressure Ulcer Advisory Panel 2009

Table 2 - Percentage of hits by participants regarding preventive measures for pressure ulcers, Manaus, Amazonas, Brazil, 2014

\begin{tabular}{|c|c|c|c|c|c|c|}
\hline \multirow{2}{*}{ Pressure ulcer prevention } & \multicolumn{2}{|c|}{ Nurses } & \multicolumn{2}{|c|}{$\begin{array}{l}\text { Nursing } \\
\text { technicians/aides }\end{array}$} & \multicolumn{2}{|c|}{ Total } \\
\hline & $\mathbf{f}$ & $\%$ & f & $\%$ & f & $\%$ \\
\hline $\begin{array}{l}2 \text { - The factors of risk to develop pressure ulcers are: immobility, incontinence, inadequate nutrition } \\
\text { and change on consciousness level }(\mathrm{T})\end{array}$ & 6 & 50.0 & 17 & 60.7 & 23 & 53.4 \\
\hline $\begin{array}{l}3 \text { - All patients in risk for pressure ulcer should have their skin systematically inspected, at } \\
\text { least once a week }(F)\end{array}$ & 7 & 58.3 & 13 & 46.4 & 22 & 51.1 \\
\hline 4 - The use of warm water and soap may dry the skin and increase the risk for pressure ulcer (T) & 4 & 33.3 & 19 & 67.8 & 24 & 55.8 \\
\hline 5 - It is important to massage the regions of bone prominence, if these have hyperemia $(\mathrm{F})$ & 7 & 58.3 & 5 & 17.8 & 13 & 30.2 \\
\hline
\end{tabular}




\begin{tabular}{|c|c|c|c|c|c|}
\hline \multicolumn{2}{|c|}{ Nurses } & \multicolumn{2}{|c|}{$\begin{array}{c}\text { Nursing } \\
\text { technicians/aides }\end{array}$} & \multicolumn{2}{|c|}{ Total } \\
\hline f & $\%$ & f & $\%$ & $f$ & $\%$ \\
\hline 10 & 83.3 & 24 & 85.7 & 37 & 86.0 \\
\hline 4 & 33.3 & 7 & 25.0 & 13 & 30.2 \\
\hline 9 & 75.0 & 23 & 82.1 & 35 & 81.4 \\
\hline 7 & 58.3 & 22 & 78.5 & 32 & 74.4 \\
\hline 6 & 50.0 & 20 & 71.4 & 29 & 67.4 \\
\hline 7 & 58.3 & 14 & 50.0 & 24 & 55.8 \\
\hline 6 & 50.0 & 6 & 21.4 & 15 & 34.8 \\
\hline 7 & 58.3 & 17 & 60.7 & 26 & 60.4 \\
\hline 5 & 41.6 & 14 & 50.0 & 20 & 46.5 \\
\hline 5 & 41.6 & 8 & 28.5 & 15 & 34.8 \\
\hline 4 & 33.3 & 15 & 53.5 & 20 & 46.5 \\
\hline 8 & 66.6 & 23 & 82.1 & 32 & 74.4 \\
\hline 9 & 75.0 & 27 & 96.4 & 38 & 88.3 \\
\hline 8 & 66.6 & 28 & 100 & 38 & 88.3 \\
\hline 7 & 58.3 & 20 & 71.4 & 29 & 67.4 \\
\hline 5 & 41.6 & 26 & 92.8 & 33 & 76.7 \\
\hline 7 & 58.3 & 24 & 85.7 & 32 & 74.4 \\
\hline 11 & 91.6 & 27 & 96.4 & 40 & 93.0 \\
\hline 10 & 83.3 & 28 & 100 & 40 & 93.0 \\
\hline 8 & 66.6 & 26 & 92.8 & 37 & 86.0 \\
\hline 6 & 50.0 & 25 & 89.2 & 33 & 76.7 \\
\hline 10 & 83.3 & 23 & 82.1 & 34 & 79.0 \\
\hline 5 & 41.6 & 22 & 78.5 & 29 & 67.4 \\
\hline 9 & 75.0 & 24 & 85.7 & 36 & 83.7 \\
\hline 7 & 58.3 & 20 & 71.4 & 27 & 62.7 \\
\hline 4 & 33.3 & 27 & 96.4 & 34 & 79.0 \\
\hline 6 & 50.0 & 28 & 100 & 36 & 83.7 \\
\hline 12 & 100 & 26 & 92.8 & 40 & 93.0 \\
\hline 10 & 83.3 & 27 & 96.4 & 40 & 93.0 \\
\hline
\end{tabular}
during hospital stay $(F)$ 
Table 3 - Comparison of mean hit percentage between the professional groups, according to the category of knowledge, Manaus, Amazonas, Brazil, 2014

\begin{tabular}{|c|c|c|c|c|}
\hline \multirow{3}{*}{ Instrument categories } & \multicolumn{2}{|c|}{ Professional group } & \multirow{3}{*}{ Stat. test } & \multirow{3}{*}{$p$ value } \\
\hline & $\begin{array}{l}\text { Nurses } \\
(\mathrm{n}=14)\end{array}$ & $\begin{array}{l}\text { Technicians/aides } \\
(n=26)\end{array}$ & & \\
\hline & \multicolumn{2}{|c|}{ Mean and SD (\%) of hits } & & \\
\hline PU evaluation and classification & $44(20.6)$ & $55.1(16.4)$ & $t$-test $(38 \mathrm{df})=1.81$ & 0.0780 \\
\hline $\mathrm{PU}$ preventive measures & $52.9(8.7)$ & $65.1(8.9)$ & $t$-test $(38 \mathrm{df})=4.01$ & $<0.001$ \\
\hline All questions & $51.4(9.7)$ & $63.4(8.0)$ & $t$-test $(38 \mathrm{df})=4.08$ & $<0.001$ \\
\hline
\end{tabular}

Note: $p$ value, values in bold show statistically significant differences at the $5 \%$ level; Standard deviation: SD; Number of nursing staff members: $n$.

\section{DISCUSSION}

Considering the overall results of this study, we find percentage means of hits significantly higher among nursing technicians/aides in the category of preventive measures and for total questions, in comparison with nurses. All these means were quite below the cutline score established here $(90 \%)$. This fact is very concerning if we consider that nurses are in charge of training and guiding nursing technicians and aides regarding care delivered to patients.

In a study ${ }^{(11)}$ developed with the members of a nursing team in a tertiary teaching hospital in a city in São Paulo, using the same knowledge test applied in this study, the total mean of hits was similar among nurses $(79.4 \%$; SD $=8.3)$ and nursing technicians/aides $(73.6 \% ; \mathrm{SD}=9.8)$, but higher than that found in this study. According to the authors, these means show the shortage of knowledge among the whole nursing team.

In a similar study ${ }^{(12)}$, also developed in a tertiary teaching hospital in a city in São Paulo, with 35 nurses from different care units, an instrument developed by the authors was applied. The instrument addressed PU prevention and treatment. The total mean of hits for nurses was $69.4 \%$; $S D=13.5$, also higher than that found by us, showing insufficient overall and specific knowledge.

In Amman, Jordan ${ }^{(13)}$, a study using a questionnaire about PU prevention with 26 multiple-choice questions, only half of the hits was achieved by 194 nurses with a master's degree. This result is similar to that found in this study $(51.4 \%$; $\mathrm{SD}=9.7)$. A higher mean $(77.0 \%)$ was achieved in another study in Jordan $^{(14)}$ about PU prevention and treatment with higher casuistic ( $n=460$ nurses), in a public hospital. The study employed a 45-item questionnaire. Despite the different means in the three studies, all of these characterized knowledge as insufficient.

Among residents in a geriatric institution in Spain, nursing professionals, physicians and other healthcare professionals working in the urgency sector answered a questionnaire about PU prevention and treatment (33 multiple-choice questions). The overall mean of hits reached $97.7 \%$, showing an adequate level of knowledge ${ }^{(15)}$.

More satisfactory results were achieved in a Brazilian study ${ }^{(16)}$ carried out in a teaching hospital in the state of Rio Grande do Sul, where the same Pieper's Pressure Ulcer Knowledge Test was applied before and after an educational intervention about PU prevention and treatment. The nurses $(n=49)$ reported hit means of $80.54 \%$ in the pre-training phase and $86.64 \%$ in the post-training phase.

In this study a highlight is the shortage of knowledge about the PU classification system recommended by the NPUAP/ EPUAP in 2014 ${ }^{(17)}$

In a study developed with nursing team members of a tertiary teaching hospital in a city of São Paulo ${ }^{(18)}$, the mean hits by professionals regarding the description of the PU classification was low $(29.5 \%)$ as well, with negative interference in the process of clinical evaluation of patients. This also entails unfavorable consequences to the planning of proper interventions.

These consequences are well studied and grounded on research ${ }^{(19-20)}$, which emphasize the relevance of developing and implementing protocols of risk evaluation; using standardized instruments and clinical rationale; and, preventing these lesions according to international guidelines.

Another proposal defended by the authors ${ }^{(21)}$ as an intervention to prevent PU in hospital units are educational actions promoted in the institutions. These emerge as a way of training professionals and improving their individual and collective performance.

In Brazil, these measures related to the protocols of prevention and treatment and educational actions are quite limited and started being instituted by virtue of institutional accreditations for quality, including the incidence of $\mathrm{PU}$, and of the newly released National Policy of Patient Safety ${ }^{(22)}$.

\section{Limitations of the study and Contributions to the area of nursing, health or public policy}

This study had limitations related to the non-inclusion of the multi-professional health team of the institution; the inclusion of one single sector of the hospital unit; and the possibility of introducing educational intervention before and after applying the knowledge test on PU prevention and treatment, which could be done in further studies. Moreover, by allowing the identification and analysis of the main gaps of knowledge found among the nursing team members, it intends to submit the findings to public and private management authorities to develop and implement educational strategies and, in the future, protocols for PU prevention to improve the quality of nursing care provided in the Amazon Region.

The results found in this study point out the urgent need for hospital institutions to make investments in professional 
training. These could be done through continuing education services, and by providing resources to this clinical practice.

\section{CONCLUSION}

The study unveiled insufficient knowledge $(<90 \%)$ on $\mathrm{PU}$ prevention among 40 nursing professionals in the ICU of a teaching hospital in Manaus. Overall means of hit and means of hit in the categories of the Pieper's Pressure Ulcer Knowledge Test were low for both groups (51.4\%; SD $=9.7$ and $63.4 \%$; $S D=8.0$, respectively for nurses and technicians/ aides), but significantly higher among technicians/aides in the total and in the category PU preventive measures $(p<0.001)$ in comparison to nurses.

\section{REFERENCES}

1. Rolim JA, Vasconcelos JMB, Caliri MHL, Santos IBC. Prevenção e tratamento de úlceras por pressão no cotidiano de enfermeiros intensivistas. Rev Rene[Internet]. 2013[cited 2016 Mar 26];14(1):148-57. Available from: http://www.revistarene.ufc.br/revista/index.php/ revista/article/viewFile/336/pdf

2. Silva EWNL, Araújo RA, Oliveira EC, Falcão VTFL. Aplicabilidade do protocolo de prevenção de úlcera de pressão em unidade de terapia intensiva. Rev Bras Ter Intensiva[Internet]. 2010[cited 2016 Mar 26];22(2):175-85. Available from: http://www.scielo. $\mathrm{br} / \mathrm{pdf} / \mathrm{rbti} / \mathrm{v} 22 \mathrm{n} 2 / \mathrm{a} 12 \mathrm{v} 22 \mathrm{n} 2$

3. Liu M, Chen W, Liao Q, Gu Q, Hsu M, Poon A. Validation of two pressure ulcer risk assessment scales among Chinese ICU patients. Rev Enf Ref[Internet]. 2013[cited 2016 Mar 26];serllI(9):145-50. Available from: http://www.scielo.mec.pt/pdf/ref/vserllln9/serlllnn9a15.pdf

4. Dantas DV, Torres GV, Dantas RAN. Assistência aos portadores de feridas: caracterização dos protocolos existentes no brasil. Rev Cienc Cuid Saude[Internet]. 2011[cited 2016 Mar 26];10(2):366-72. Available from: http://periodicos.uem.br/ojs/index.php/ CiencCuidSaude/article/view/8572

5. Talsma A, Tschannen D, Guo Y, Kazemi J. Evaluation of the pressure ulcer prevention clinical decision report for bedside nurses in acute care hospitals. Appl Clin Inform[Internet]. 2011[cited 2016 Mar 26];2(4)508-21. Available from: http://www.ncbi.nlm.nih.gov/pmc/ articles/PMC3612994

6. Beeckman D, Defloor T, Schoonhoven L, Vanderwee K. Knowledge and attitudes of nurses on pressure ulcer prevention: a cross-sectional multicenter study in Belgian hospitals. Worldviews Evid Based Nurs[Internet]. 2011[cited 2016 Mar 26];8(3):166-76. Available from: http://onlinelibrary.wiley.com/doi/10.1111/j.1741-6787.2011.00217.x/epdf

7. Mauricio $\mathrm{AB}$, Lemos DS, Crosewski NI, Roehrs $\mathrm{H}$. Conhecimentos dos profissionais de enfermagem relacionados às úlceras por pressão. Rev Enferm UFSM[Internet]. 2014[cited 2016 Mar 26];4(4):751-60. Available from: https://periodicos.ufsm.br/reufsm/article/ download/11707/pdf

8. Sving E, Högman M, Mamhidir AG, Gunningberg L. Getting evidence-based pressure ulcer prevention into practice: a multi-faceted unittailored intervention in a hospital setting. Int Wound J[Internet]. 2014[cited 2016 Mar 26];13(5)645-54 Available from: http://onlinelibrary. wiley.com/doi/10.1111/iwj.12337/full

9. Pieper B, Mott M. Nurses' knowledge of pressure ulcer prevention, stating, and description. Adv Wound Care[Internet]. 1995[cited 2016 Mar 26];8(3):34-48. Available from: http://europepmc.org/abstract/med/7795877

10. Fernandes LM, Caliri MHL, Haas VJ. Efeito de intervenções educativas no conhecimento dos profissionais de enfermagem sobre prevenção de úlceras pressão. Acta Paul Enferm[Internet]. 2008[cited 2016 Mar 26];21(2):305-11. Available from: http://www2.unifesp.br/acta/pdf/v21/ n2/v21n2a12.pdf

11. Miyazaki MY, Caliri MHL, Santos CB. Conhecimento dos profissionais de enfermagem sobre prevenção da úlcera por pressão. Rev Latino-Am Enfermagem[Internet]. 2010[cited 2016 Mar 26];18(6):[10 pages]. Available from: http://www.scielo.br/pdf/rlae/v18n6/pt 22

12. Rogenski NMB, Kurcgant P. Incidência de úlceras por pressão após a implementação de um protocolo de prevenção. Rev LatinoAm Enfermagem[Internet]. 2012[cited 2016 Mar 26];20(2):[07 pages]. Available from: http://www.scielo.br/pdf/rlae/v20n2/pt_16

13. Qaddumi J, Khawaldeh A. Pressure ulcer prevention knowledge among Jordanian nurses: a cross-sectional study. BMC Nurs[Internet]. 2014[cited 2016 Mar 26];13:6. Available from:http://www.biomedcentral.com/1472-6955/13/6

14. Saleh MYN, Al-Hussami M, Anthony D. Pressure ulcer prevention and treatment knowledge of Jordanian nurses. J Tissue Viability[Internet]. 2013[cited 2016 Mar 26];22:1-11. Available from: http://www.sciencedirect.com/science/article/pii/S0965206X13000041

15. Caballero $\mathrm{DH}$. Conocimiento de los profesionales de urgencias sobre la prevención y tratamiento de las úlceras por presión. Gerokomos[Internet]. 2012[cited 2016 Mar 26];23(4):178-84. Available from: http://scielo.isciii.es/pdf/geroko/v23n4/helcos1.pdf

16. Soares RSA, Saul AMR, Silva RM, Timm AMB, Bin A, Durgante VL. Intervenção educativa como processo de construção do conhecimento no cuidado da úlcera por pressão. Rev Enferm UFPE[Internet]. 2014[cited 2016 Mar 26];8(6):1658-65. Available from: http://www. revista.ufpe.br/revistaenfermagem/index.php/revista/article/download/5148/

17. National Pressure Ulcer Advisory Panel - NPUAP[Internet]. 2015[cited 2016 Mar 26]; Available from: http://www.npuap.org

18. Simão CMF, Caliri MHL, Santos CB. Concordância entre enfermeiros quanto ao risco dos pacientes para úlcera por pressão. Acta Paul Enferm[Internet]. 2013[cited 2016 Mar 26];26(1):30-5. Available from: http://www.scielo.br/pdf/ape/v26n1/06.pdf 
19. Silva EWNL, Araújo RA, Oliveira EC, Falcão VTFL. Aplicabilidade do protocolo de prevenção de úlcera de pressão em unidade de terapia intensiva. Rev Bras Ter Intensiva[Internet]. 2010[cited 2016 Mar 26];22(2):175-85. Available from: http://www.scielo.br/pdf/rbti/v22n2/ a12v22n2

20. Almeida RA, Bastos RAA, Almeida FCA, Pequeno GA, Vasconcelos JMB, Rodrigues FA. Avaliação da utilização de protocolos na prevenção de úlceras por pressão. Rev Ciênc Saúde[Internet]. 2012[cited 2016 Mar 26];5(2):125-31. Available from: http:// revistaseletronicas.pucrs.br/ojs/index.php/faenfi/article/view/10457/8207

21. Minami LF, Santos PT, Ferrari CRS, Ciampone MHT, Messas JT, Mira VL. Avaliação do treinamento "Prevenção e tratamento de Úlcera por Pressão" ministrado à equipe de enfermagem. Rev Eletr Enf[Internet]. 2012[cited 2016 Mar 26];14(3):663-70. Available from: https://www.fen.ufg.br/fen_revista/v14/n3/pdf/v14n3a24.pdf

22. Brasil. Ministério da Saúde. Segurança do Paciente: Programa Nacional de Segurança do Paciente (PNSP): estado da arte e perspectiva. Portaria n$^{\circ}$ 529, de 1 de Abril de 2013: Programa Nacional de Segurança do Paciente para monitoramento e prevenção de danos na assistência à saúde. Brasília (DF); 2013. 